\title{
PENETRASI PASAR DENGAN MENGGUNAKAN ANALISIS PESTLE: STUDI KASUS DI PT. HSI CABANG BANDUNG
}

\author{
Eko Riwayadi, Novtri Mariatie
}

Universitas Pelita Bangsa, Bekasi, Indonesia.

Email: eko.riwayadi@mhs.pelitabangsa.ac.id,novtri.m@gmail.com

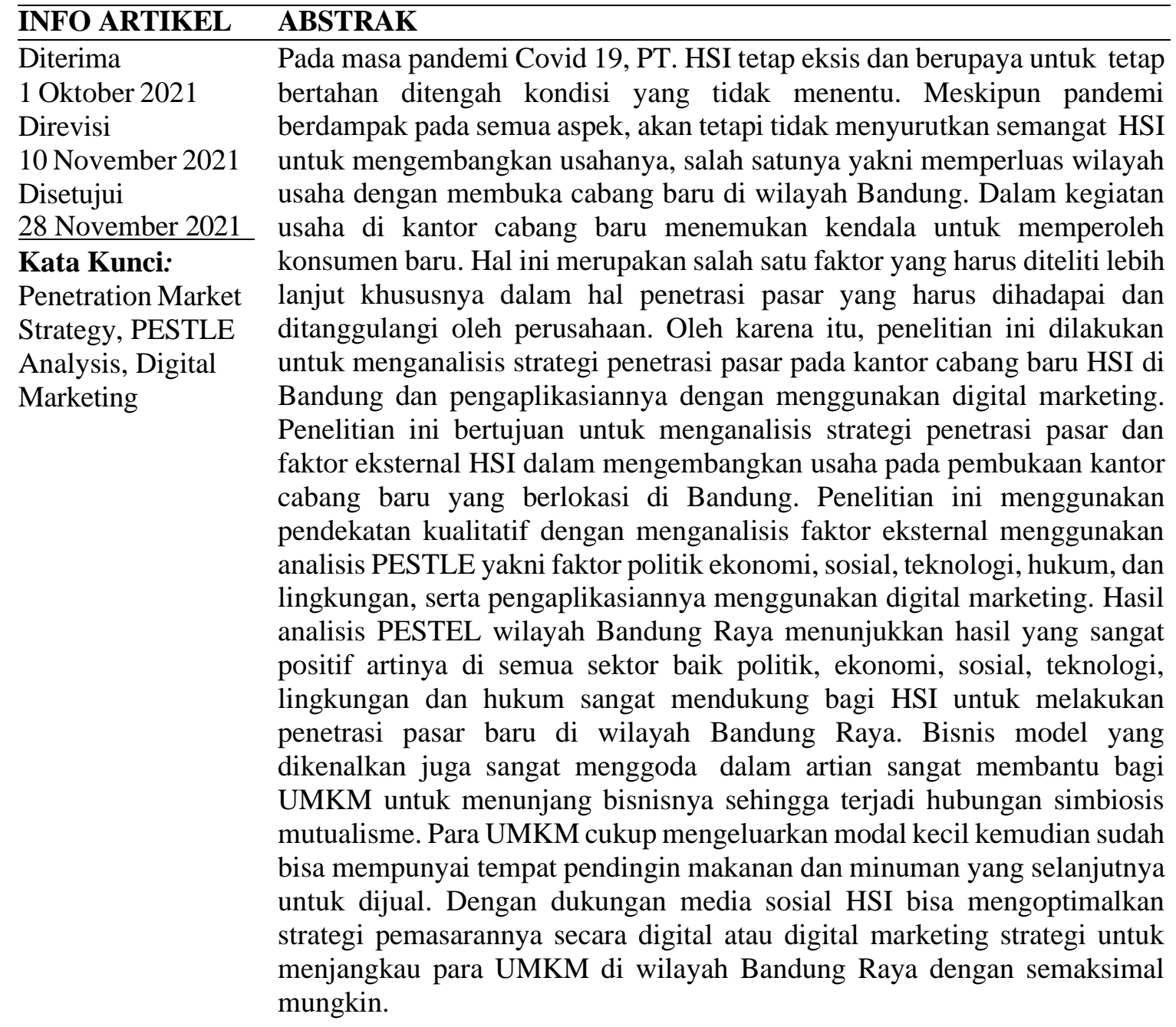

\section{ABSTRACT}

During the Covid 19 pandemic, PT. HSI still exists and strives to stay afloat in the midst of uncertain conditions. Although the pandemic impacted all aspects, it did not dampen HSI's spirit to develop its business, one of which is expanding the business area by opening a new branch in the Bandung area. In business activities in new branch offices find obstacles to acquiring new consumers. This is one of the factors that must be further investigated, especially in terms of market penetration that must be addressed and addressed by the company. Therefore, this research was conducted to analyze market penetration strategies at HSI's new branch 


office in Bandung and its application using digital marketing. This
research aims to analyze HSI's market penetration strategy and external
factors in developing the business at the opening of a new branch office
located in Bandung. This research uses a qualitative approach by
analyzing external factors using PESTLE analysis, namely economic,
social, technological, legal, and environmental political factors, and its
application using digital marketing. Pestel analysis results in the Greater
Bandung area showed very positive results meaning that in all sectors both
political, economic, social, technological, environmental and legal are
very supportive for HSI to penetrate new markets in the Greater Bandung
area. The business model introduced is also very tempting in the sense that
it is very helpful for MSMEs to support their business so that there is a
symbiotic relationship of mutualism. The MSMEs simply spend a small
capital then can already have a place to cool food and drinks that are next
Penetration
Market Strategy,
PESTLE Analysis, to bold. With the support of social media HSI can optimize its marketing
Sigital Marketing digitally or digital marketing strategy to reach MSMEs in the
Greater Bandung area as much as possible.

\section{Pendahuluan}

Pandemik Covid 19 yang mulai merebak pada kuartal 3 tahun 2019 tetah memporak-porandakan kehidupan manusia dan perekonomian dunia. Kebiasaan kehidupan yang bebas dipaksa untuk berhenti guna menghambat laju penyebaran virus covid 19. Perekonomian dunia sangat melemah pada akhir tahun 2020 GDP growth dunia $-3,41$ persen padahal di akhir 2019 growth 2,56 persen (The World Bank, 2021)

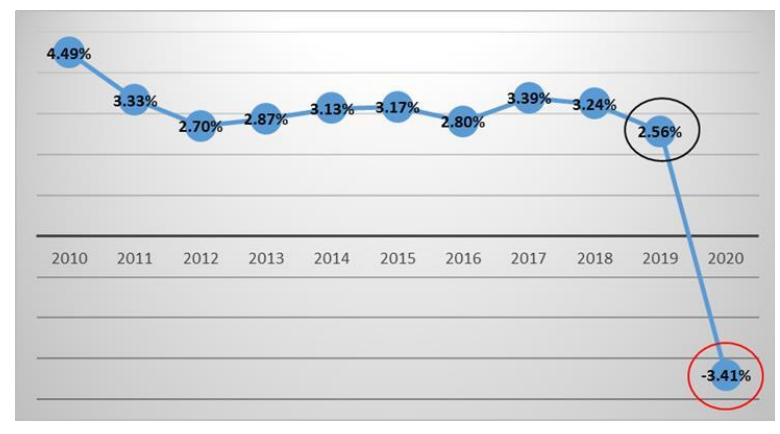

Sumber: The World Bank, tahun 2021

Gambar 1

Grafik GDP Growth tahun 2010 - 2020

Sama halnya di perekonomian Indonesia melemah disebabkan oleh pandemic covid 19. GDP growth tahun 2020 sebesar 2,07 persen padahal di tahun 2019
GDP growth sebesar 5,02 persen (The World Bank, 2021).

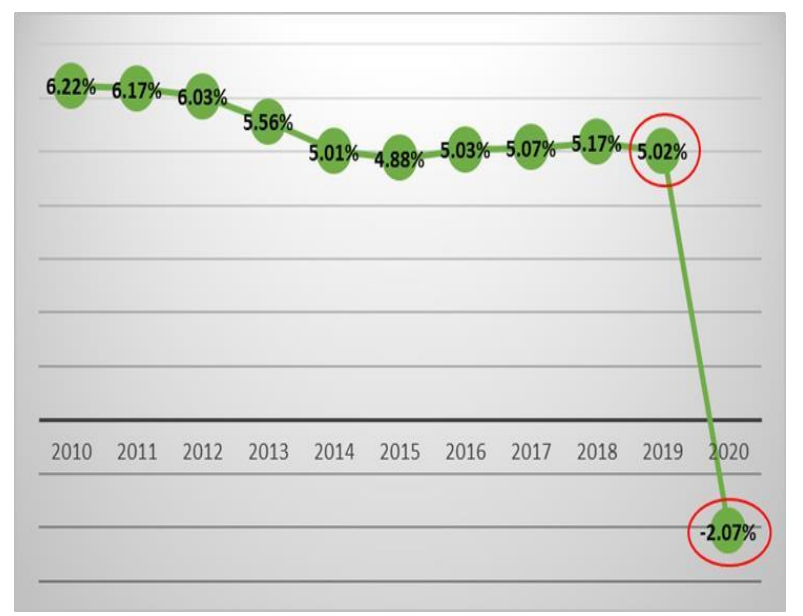

Sumber: The World Bank, tahun 2021

Gambar 2. Grafik GDP Indonesia Growth tahun 2010 - 2020

Para pelaku usaha tidak henti-hentinya merumuskan strategi yang paling optimal supaya perusahaannya tetap bertahan di tengah badai covid 19. PT. Hutama Solusi Indonesia atau yang lebih dikenal dengan PT. HSI atau HSI juga merumuskan dan melaksanakan strategi bisnis untuk bertahan dan berkembang dalam rangka menghadapi gempuran covid 19. Hal ini dikarenakan revenue perusahaan juga menurun sebagai akibat merebaknya pandemic covid 19 (Dugguh et al., 2018). 


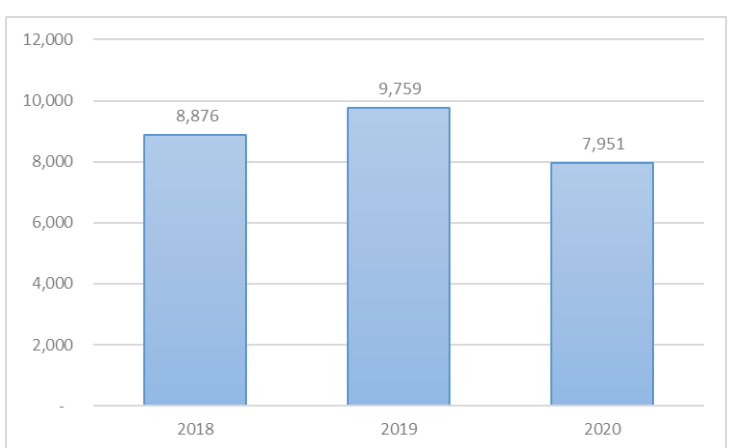

Sumber: Finance data PT. HIS

Gambar 3. Grafik revenue PT. HSI tahun

2018 2020 dalam jutaan rupiah

HSI adalah perusahaan perdagangan barang-barang elektronics khususnya cooler dan freezer yang mempunyai cakupan wilayah di seluruh Indonesia. Di musim pandemic HSI meluncurkan product bisnis baru yaitu rental cooler dan freezer yang telah beroperasi di wilayah Jabodetabek. Ternyata bisnis rental cooler dan freezer ini berkembang cukup pesat dan HSI berusaha untuk mengembangkan wilayah operasionalnya ke Bandung Raya. Namun rupanya penetrasi pasar ke wilayah Bandung Raya tidak semulus operasional di wilayah Jabodetabek. Semenjak 1-Agustus-2021 HSI membuka cabang baru di Bandung Raya hingga akhir September 2021 baru mendapatkan 3 pelanggan. Hal ini sangat menantang peneliti untuk mengetahui permasalahan apa yang terjadi sesungguhnya, kenapa suatu product bisnis yang sukses di Jabodetabek tidak mudah untuk di terapkan di Bandung Raya. Novelty yang diharapkan dari penelitian ini adalah untuk mengungkap salah satu atau beberapa sumber masalah yang mengakibatkan penetrasi pasar tidak berlangsung sukses (Eliyana et al., 2020).

\section{Metode Penelitian}

Metode penelitian ini menggunakan pendekatan deskriptif kualitatif (Moleong, 2013). Penelitian melibatkan faktor-faktor yang terdapat pada analisa PESTEL yang merupakan struktur kualitatif dalam melakukan evaluasi terhadap lingkungan makro di luar perusahaan (Yüksel, 2012). Data primer diperoleh dari HSI dengan cara melakukan observasi dan interview dengan para pimpinan dan karyawan HSI sebagai informan kunci. Data primer diperoleh dari website The World Bank. Penelitian ini berfokus pada analisis dengan melihat faktor eksternal yang terdiri dari Politik, Ekonomi, Sosial, Teknologi, Hukum, dan Lingkungan (PESTLE) dalam strategi penetrasi pasar cabang baru PT. HSI di wilayah Bandung.

Tahapan pengumpulan data dalam penelitian ini menurut (Nugrahani \& Hum, 2014) yakni (1) studi literatur, (2) analisa eksternal terhadap perkembangan HSI di kantor cabang Bandung dan (3) interview dengan para informan kunci untuk mengetahui permasalhan, potensi, pangsa pasar serta competitor HSI kantor cabang Bandung.

\section{Hasil dan Pembahasan}

A. Gambaran Ekonomi Bandung Raya Berdasarkan PESTLE Analisis

1. Analisa Faktor Politik

Pelaksanaan UU No.23 Tahun 2014 di Kota Bandung bila melihat dari segi politik maka ditandai dengan program legislatif tentang pembahasan perubahan peraturan terhadap struktur organisasi dan tata kerja, serta mitra pemerintah daerah yakni DPRD dan kegiatan partai politik tingkat daerah. Dalam melaksanakan otonomi daerah, pemerintah kota Bandung secara administratif melakukan rekognisi kewenangan pemerintah daerah, menempatkan personil, menata kelembagaan, mengelola asset daerah dari segi sarana dan prasarana, dan mengelola sumber keuangan daerah, serta manajemen pelayanan publik.

Kota Bandung sebagai daerah otonomi memiliki kewenangan yang mencakup di berbagai bidang 
pemerintahan. Kewenangan tersebut tidak termasuk pada kewenangan di bidang pertahanan dan keamanan, politik luar negeri, moneter dan fiskal, bidang agama, peradilan, agama, dan bidang kewenangan lainnya yang terdiri dari perimbangan keuangan, kebijakan perencanaan nasional, pengendalian secara makro, sistem administrasi negara, pembinaan dan pemberdayaan SDM, pendayagunaan SDA, konservasi dan standarisasi nasional, serta teknologi tinggi yang strategis.

Pemerintah Kota Bandung memiliki tugas dalam pelaksanaan penyelenggaraan pemerintahan, pembangunan dan juga memberikan pelayanan prima kepada masyarakat sehingga dapat mewujudkan masyarakat Kota Bandung yang bermartabat dan Bandung yang unggul, nyaman, sejahtera dan agamis. Dengan adanya otonomi daerah dan dukungan dari pemerintah setempat khususnya terhadap para pelaku usaha maka dapat memberikan peluang usaha bagi HSI dalam mengembangkan usahanya di kota Bandung

2. Analisa Faktor Ekonomi

Data badan pusat statistik (BPS) menyebutkan bahwa laju pertumbuhan ekonomi kota Bandung selama periode tahun 2010 hingga 2019 merupakan yang tertinggi di wilayah Jawa Barat dengan angka sebesar 7,6 persen per tahun. Hal ini tidak lepas dari keunggulan setiap sektor yang terdapat di kota Bandung (Badan Pusat Statistik Kota Bandung, 2020).

Produk Domestik Regional Bruto (PDRB) berdasarkan lapangan usaha yang dikeluarkan oleh BPS, terdapat tiga sektor utama dengan kontribusi paling besar bagi kota Bandung di tahun 2019 dimana gabungan jumlah ketiga faktor dapat melampaui setengah dari perekonomian kota Bandung. Ketiga sektor tersebut yaitu sektor komunikasi (14 persen), sektor industri pengolahan (19 persen), dan sektor perdangan besar \& eceran (28 persen). Sektor perdagangan besar dan eceran berkontribusi paling besar dengan kisaran angka 23-24 persen, dimana angka ini sekaligus yang paling tinggi di tingkat provinsi Jawa Barat per tahun 2019. Sektor tersebut sangat dipengaruhi oleh faktor eksternal, salah satunya yakni distribusi barang. Kelancaran distribusi barang menjadi yang paling utama agar dapat mengembangkan sektor ini.

Berdasarkan hasil analisis ahli ekonomi INJABAR UNPAD, pada masa pandemi Covid-19 di akhir tahun 2020 terdapat pertumbuhan ekonomi Kota Bandung sebesar 0,58 persen (Mediaindonesia.com, 2020) . Hal ini menyebabkan terjadinya perlambatan pertumbuhan ekonomi Kota Bandung di tahun 2020 secara drastis. Daya beli masyarakat menurun sehingga pertumbuhan ekonomi di kota Bandung mengalami kontraksi yang mengakibatkan kontribusi menjadi menurun. Data pada Dinas KUKM Kota Bandung menyatakan bahwa terdapat 996 pelaku usaha UKM Kota Bandung dari berbagai sektor usaha yang turut mengalami dampak akibat wabah pandemi Covid-19, sehingga mengalami kekurangan modal, kesulitan dalam hal pemasaran, juga mengakibatkan penurunan omset (Badan Pusat Statistik Kota Bandung, 2020).

Melihat hal tersebut maka pemerintah kota Bandung berupaya meningkatkan pertumbuhan perekonomian di kota Bandung dengan 
mendorong dan mendukung para pelaku usaha. Usaha mikro, kecil, dan menengah (UMKM) pada masa pandemi Covid-19 ini merupakan sektor yang paling bertahan mengahadapi krisis. Wakil walikota Bandung, Yana Mulyana mengatakan bahwa pemerintah setempat mendukung para pelaku UMKM untuk terus berkreasi dan melakukan inovasi dengan memberikan pelatihan dan pembinaan.

Menurut kepala Dinas KUMKM

kota Bandun, Atet Dedi $\mathrm{H}$ mengemukakan bahwa terdapat permasalahan yang timbul akibat pandemi Covid-19 yakni banyak UMKM terkendala masalah pemasaran. Untuk mengatasai hal tersebut maka dinas KUMKM kota Bandung membuat kebijakan-kebijakan dan salah satunya yakni memberikan relaksasi perpajakan dan memfasilitasi bantuan permodalan bagi para pelaku UMKM. Selain itu juga pemerintah setempat berupaya untuk melakukan kolaborasi dengan para stakeholder yang berhubungan dengan pelaku UMKM di kota Bandung.

Menurut hasil analis INJABAR UNPAD bahwa pertumbuhan ekonomi di Kota Bandung tetap mengalami pertumbuhan ekonomi yang positif meskipun relatif kecil, dan hal ini masih lebih baik jika dibandingkan dengan pertumbuhan ekonomi nasional dan provinsi Jawa Barat dimana laju pertumbuhan ekonominya masih negatif pada tahun 2020 .

Berdasarkan gambaran ekonomi di kota Bandung tersebut maka dapat disimpulkan bahwa pertumbuhan ekonomi di kota Bandung masih dapat berkembang dengan cukup baik dan memiliki potensi peluang usaha yang cukup luas meskipun di tengah kondisi pandemi saat ini karena adanya dukungan dari pemerintah daerah setempat. Oleh karena itu, masih membuka peluang yang cukup luas bagi PT.HSI dalam mengembangkan usahanya di wilayah kota Bandung.

3. Analisa Faktor Sosial

Kota Bandung merupakan salah satu kota yang menjadi daya tarik migrasi di Jawa Barat dan hal ini berpengaruh terhadap tingginya perkembangan jumlah penduduk di kota Bandung. Menurut data Dinas Kependudukan dan Pencatatan Sipil kota Bandung, pada tahun 2019 jumlah penduduk Kota Bandung sebanyak 2.480.464 jiwa, dan pada tahun 2020 jumlah penduduk Kota Bandung berjumlah 2.490.386 jiwa. Berdasarkan data tersebut maka dapat terlihat bahwa terjadi kenaikan jumlah penduduk di Kota Bandung pada setiap tahunnya.

Pemerintah kota Bandung menjadikan warganya sebagai insan yang religius mencakup pendidikan, kesehatan, keagamaan serta taat kepada hukum dan aturan yang berlaku sehingga terwujud keamanan, kenyamanan dan ketertiban kota. Dengan dukungan masyarakat melalui upaya yang cerdas dan terarah maka akan tercapai kesejahteraan dan kemakmuran masyarakat. Pemerintah kota Bandung pun mengembangkan sosial budaya kota yang ramah dengan kesadaran tinggi dan memiliki hati nurani sehingga dapat meningkatkan ketenagakerjaan dan kesejahteraan sosial. Oleh karena itu, kehadiran HSI di kota Bandung dalam rangka mendukung upaya pemerintah setempat dalam mengembangkan sosial budaya kota Bandung sehinga ketenagakerjaan dan kesejahteraan sosial di kota Bandung akan semakin meningkat. 
4. Analisa Faktor Teknologi

Penggunaan teknologi sudah digunakan dan dimanfaatkan dengan cukup aktif oleh Sebagian besar warga kota bandung. Hal ini terlihat dari data statistik kesejahteraan rakyat kota Bandung (Badan Pusat Statistik, 2019) bahwa 82 persen penduduk kota Bandung yang berusia lima tahun ke atas adalah pengguna aktif gawai seperti komputer, laptop, dan telepon seluler. Sedangkan 73 persen penduduk kota Bandung merupakan pengguna akses internet.

Perkembangan UMKM di kota Bandung pun diiringi dengan perkembangan dan penguasaan teknologi. Saat ini banyak para pelaku UMKM di kota Bandung menggunakan teknologi sebagai sarana informasi dan pelayanan terhadap konsumen. Dengan penggunaan teknologi ini maka para pelaku UMKM dapat turut bersaing dengan para pelaku industri menengah dan besar serta dapat menunjang perkembangan bisnis UMKM ke arah yang lebih baik.

Menurut Yana Mulyana, selaku wakil walikota Bandung mengatakan bahwa pemerintah kota Bandung mendorong para pelaku UMKM peka terhadap teknologi dan menggunakan pemasaran secara online melalui marketplace. Pemerintah setempat pun memberikan pelatihan digitak marketing, mendukung produk-produk UMKM melalui akun media sosial, dan menggeser desai-desain yang konservatif.

Berdasarkan faktor teknologi yang ada di kota Bandung maka hal tersebut dapat mendukung perkembangan usaha HSI di kota Bandung khususnya melalui digital marketing. Dengan demikian HSI dapat dikenal lebih luas oleh seluruh warga kota Bandung dan khususnya bagi para pelaku usaha yang hendak berkolaborasi dengan HSI.

5. Analisa Faktor Lingkungan

Kota Bandung adalah ibu kota provinsi Jawa Barat dan merupakan kota metropolitan terbesar yang terletak di provinsi Jawa Barat. Wilayah Bandung Raya merupakan kota metropolitan terbesar ketiga di Indonesia. Melihat dari letak geografisnya maka kota Bandung memiliki lokasi yang sangat strategis khususnya dalam hal perekonomian nasional karena berada di lokasi pertemuan jalan utama di pulau Jawa. Kota Bandung disebut sebagai kota kembang, dikarenakan pada zaman dahulu di kota Bandung tumbuh berbagai macam pepohonan dan bungabunga cantik. Kota Bandung pun disebut dengan Parijs van Java, dikarenakan keindahan kotanya yang menyerupai kota paris. Selain itu kota Bandung juga disebut sebagai kota belanja, dimana banyak pusat perbelanjaan seperti mal dan factory outlet yang tersebar di seluruh kota ini. Saat ini kota Bandung pun dikenal sebagai kota wisata kuliner, dimana tersedia berbagai aneka kuliner yang unik dan inovatif. Pada tahun 2007, kota Bandung dinobatkan sebagai pilot project kota terkreatif se-Asia timur oleh konsorsium beberapa LSM internasional. Saat ini, kota Bandung telah menjadi salah satu kota destinasi utama bagi para wisatawan.

Dengan segala daya tarik lingkungan yang telah dimiliki oleh kota Bandung maka hal ini dapat mendukung HSI untuk membuka dan mengembangkan usahanya di wilayah kota Bandung. 
6. Analisa Faktor Hukum

Dengan adanya pandemi Covid-

19 maka presiden Jokowi mengeluarkan Keputusan Presiden No.11 Tahun 2020 mengenai Penetapan Kedaruratan Kesehatan Masyarakat Covid-19 sebagai darurat kesehatan masyarakat. Dalam rangka upaya menekan penyebaran virus corona maka pemerintah pun segera membentuk gugus tugas percepatan penanganan Covid-19 melalui Keppres Nomor 9 Tahun 2020 mengenai Perubahan atas Keppres Nomor 7 Tahun 2020.

Dalam rangka percepatan penanganan Covid-19 maka diberlakukan Pembatasan Sosial Berskala Besar (PSBB) sebagai salah satu upaya untuk mencegah terjadinya kemungkinan penyebaran Covid-19 secara meluas. PSBB ditetapkan melalui Peraturan Pemerintah (PP) Nomor 21 Tahun 2020 tentang PSBB dalam rangka Percepatan Penanganan Covid19. Dengan diberlakukannya PSBB maka kebijakannya memfokuskan pada pembatasan kegiatan tertentu bagi seluruh penduduk dalam suatu wilayah yang di duga terinfeksi Covid-19.

Penerapan PSBB berakibat terhadap banyak faktor terutama perekonomian kota Bandung. Dengan adanya pembatasan kegiatan sosial ekonomi masyarakat mengakibatkan aktivitas ekonomi yakni proses produksi, konsumsi dan distribusi mengalami hambatan. Para pelaku usaha banyak yang mengalami penurunan pendapatan dan omset yang cukup signifikan. Transaksi barang dan jasa pun berkurang sehingga berdampak terhadap tenaga kerja. Banyak tenaga kerja yang dirumahkan bahkan mendapatkan pemutusan hubungan kerja. Hal ini memprediksi bahwa jumlah pengangguran meningkatkan akibat kehilangan pekerjaan. oleh karena itu pertumbuhan ekonomi perlu ditingkatkan sehingga dapat memberikan peluang kesempatan kerja baru serta dapat memberikan kesempatan industri untuk meningkatkan output dalam rangka meningkatkan penggunaan faktor produksi.

PT.HSI hadir di kota Bandung sebagai salah satu peluang kesempatan kerja bagi para tenaga kerja yang kehilangan pekerjaannya dan sekaligus sebagai pelaku usaha yang turut mendukung pertumbuhan perekonomian kota Bandung ke arah yang lebih baik.

7. Pesaing yang sudah ada

Observasi yang yang dilakukan di HSI ditemukan bahwa beberapa pesaing disektor bisnis yang sama telah bermunculan di Bandung raya. Informan satu yang merupakan sales representatif HSI Bandung Raya menyatakan bahwa setidaknya ada dua perusahaan sejenis yang telah beroperasi di wilayah Bandung Raya, meskipun demikian informan dua yang merupakan Direktur Penjualan HSI menyatakan bahwa kehadiran pesaing tidak menjadi permasalahan atau hambatan untuk melakukan penetrasi pasar. Informan dua yakin bahwa produk dan bisnis model yang diusung perusahaannya akan bisa memenangkan persaingan. Informan dua menerangkan bahwa berdasarkan pengalaman merintis bisnis di wilayah Jabodetabek yang penuh dengan persaingan ketat, HSI berhasil menjalan bisnis rental cooler dan freezer. Keberhasilan perususahaan dapat dilihat pada tabel berikut: 
8. Pangsa Pasar UMKM Makanan dan Minuman (kuliner dan lain-lain)

Bandung Raya adalah kota besar yang berhawa sejuk dan menjadi destinasi wisata banyak warga propinsi Jawa Barat bahkan juga dari luar propinsi tersebut. Banyak sekali UMKM khususnya yang berhubungan dengan makanan dan minuman. Para UMKM dibidang makanan dan minuman sangat membutuhkan cooler dan freezer untuk menyimpan bahan makanan atau minuman yang sudah jadi supaya tidak cepat rusak. Berdasarkan analisis di sektor ekonomi pertumbuhan ekonomi Bandung Raya sebesar 7,6 persen per tahun dan sektor UMKM memberikan konstribusi yang sangat signifikan. Interview yang dilakukan peneliti dengan informan 1 yang merupakan warga asli Bandung, membernarkan bahwa sesungguhnya jumlah UMKM bidang kuliner diwilayah Bandung sangat besar terbukti dengan banyaknya UMKM hampri di sepanjang jalanan Bandung Raya. Informan 1 sangat yakin bahwa bisnis rental cooler dan freezer akan sangat di minati oleh para UMKM sektor kuliner karena hanya dengan bermodalkan uang yang tidak terlalu besar para UMKM sudah bisa memiliki ruangan pendingin untuk menyimpan makanan dan minuman yang selanjutnya dijual kepada para pelanggan UMKM. Sependapat dengan Informan 1, informan 2 menyatakan bahwa antara HSI dan Para UMKM bidang kuliner terjadi hubungan simbiosis mutualisme artinya saling membutuhkan dan saling menguntungkan.

9. Aplikasi Digital Marketing

Menurut (Chaffey \& EllisChadwick, 2019) era industri 4.0 yang ditandai dengan maraknya digitalisasi tidak luput dari pemantauan manajemen HSI. Perusahaan ini menggunakan kecanggihan teknologi digital untuk melakukan pemasaran produkproduknya. Informan 2

menyatakan bahwa pemasaran digital dengan memanfaatkan platform media sosial menjadi ujung tombak strategi pemasaran perusahaan. Platform media sosial seperti Instagram (IG) dan Facebook (FB) menjadi andalan utama untuk memasarkan produk-produk HSI. Pertimbangannya adalah sederhana saja, yakni di jaman yang serba digital ini banyak sekali masayarakat UMKM Bandung raya yang juga memasarkan produk-produk UMKM melalui platform media sosial.

Penggunaan media sosial ini juga harus dibarengi dengan kecapakan seorang sales representative yang handal untuk melakukan closing business. Artinya kesepakatan bisnis retail atau untuk mendapatkan pelanggan baru yang mau membeli atau menyewa cooler dan freezer diperlukan penjelesan spesifikasi produk, harga jual atau harga sewa yang tepat, perbaikan produk yang yang cepat dan lain sebaginya sehingga pada akhirnya calon pelanggan menjadi setuju untuk beli atau sewa cooler/freezer dari HSI.

Berdasarkan hasil penelitian yang dibuat oleh (Alang, 2009) Personal skill dari seorang sales representatif perlu terus dibangun dan belajar dari kesuksesan sales representatif di kantor pusat yang ada di Jakarta. Manajemen HSI rutin melakukan review dan pelatihan kepada sales representatif yang ada di Bandung secara virtual dengan menggunakan platform komunikasi zoom dan WA Group conference, sekali lagi keberadaan media digital 
sangat menunjang operasioanal perusahaan seperti yang diterangkan Informan 3 yang merupakan direktur operasional HSI.

\section{Kesimpulan}

Analisa PESTEL wilayah Bandung Raya menunjukkan hasil yang sangat positif artinya di semua sektor baik politik, ekonomi, sosial, teknologi, lingkungan dan hukum sangat mendukung bagi HSI untuk melakukan penetrasi pasar baru di wilayah Bandung Raya. Bisnis model yang dikenalkan juga sangat menggoda dalam artian sangat membantu bagi UMKM untuk menunjang bisnisnya sehingga terjadi hubungan simbiosis mutualisme. Para UMKM cukup mengeluarkan modal kecil kemudian sudah bisa mempunyai tempat pendingin makanan dan minuman yang selanjutnya untuk dijual. Dengan dukungan media sosial HSI bisa mengoptimalkan strategi pemasarannya secara digital atau digital marketing strategi untuk menjangkau para UMKM di wilayah Bandung Raya dengan semaksimal mungkin.

\section{Bibliografi}

Alang, S. (2009). Analisis Dan Optimalisasi Dalam Menjual" Personal Selling Skill In Sales Magic". Jurnal Perspektif, 7(2). Google Scholar

Badan Pusat Statistik Kota Bandung. (2020). Persentase Rumah yang Menerima Program Indonesia Pintar (PIP) dalam Bulan Agustus 2019-Maret 2020, Jenis PIP, dan Rata-rata PIP yang Diterima di Kota Bandung 2020. https://bandungkota.bps.go.id/statictable /2021/06/30/1543/persentase-rumahyang-menerima-program-indonesiapintar-pip-dalam-bulan-agustus-2019- maret-2020-jenis-pip-dan-rata-rata-pipyang-diterima-di-kota-bandung-

2020.html

Chaffey, D., \& Ellis-Chadwick, F. (2019). Digital marketing. Pearson uk. Google Scholar

Dugguh, S. I., Aki, I., \& Isaac, S. O. (2018). Impact of Growth Strategies on Business Profit A Study of Ashakacem Plc, Gombe-Nigeria. IOSR Journal of Business and Management (IOSR-JBM), 20(2), 23-29. Google Scholar

Eliyana, F., Nurhadi, E., \& Yektiningsih, E. (2020). Penetrasi Pasar Hasil Pertanian Kebunsayur Surabaya. Berkala Ilmiah Agridevina, 9(2), 90-102. Google Scholar

Mediaindonesia.com. (2020). WJIS 2020 Menilik Optimisme Perekonomian Jawa Barat. https://mediaindonesia.com/nusantara/3 62011/wjis-2020-menilik-optimismeperekonomian-jawa-barat

Moleong, L. J. (2013). Metode Penelitian Kualitatif, Bandung: Remaja Rosdakarya. Mosal. Google Scholar

Nugrahani, F., \& Hum, M. (2014). Metode penelitian kualitatif. Solo: Cakra Books. Google Scholar

The World Bank. (2021). GDP growth (annual \%). https://data.worldbank.org/indicator/NY. GDP.MKTP.KD.ZG

Yüksel, I. (2012). Developing a multi-criteria decision making model for PESTEL analysis. International Journal of Business and Management, 7(24), 52. Google Scholar

\section{Copyright holder :}

Eko Riwayadi, Novtri Mariatie (2021)

First publication right :

Action Research Literate

This article is licensed under:

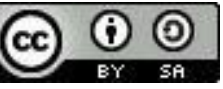

